\title{
Oligonucleotide Primer
}

National Cancer Institute

\section{Source}

National Cancer Institute. Oligonucleotide Primer. NCI Thesaurus. Code C1451.

Short DNA oligonucleotide chains used to prime DNA (and in some cases RNA) synthesis. 